\title{
Hubungan Usia dan Konsumsi Makanan Berlemak dengan Kolesterol Total Pada Lansia Kelurahan Serengan Surakarta
}

\section{The Relationship of Age and Consumption of Fatty Food with Cholosterol for Elderly People in Serengan Sub-District Surakarta}

\author{
Cisillia Adhiyani*) \\ *) Akademi Analis Kesehatan Nasional Surakarta \\ *) Jln. Yos Sudarso 338 Surakarta; cisilliaadhiyani@ymail.com
}

\begin{abstract}
Intisari
Masa lanjut usia membawa penurunan fisik dan kecenderungan angka kesakitan meningkat, salah satunya penyakit jantung koroner. Penyakit ini menjadi penyebab utama dari total kematian penduduk Indonesia dan salah satu faktor resikonya adalah hiperkolesterolemia. Hiperkolesterolemia dipengaruhi diet, keturunan, usia, jenis kelamin, obesitas, stress, alkohol, dan aktivitas fisik. Penelitian ini bertujuan untuk mengetahui hubungan usia dan konsumsi makanan berlemak dengan kolesterol total.

Jenis penelitian analitik deskriptif dengan pendekatan cross sectional. Metode sampling menggunakan purposive sampling. Data penelitian dianalisis dengan program SPSS versi 16.0

Jumlah lansia laki-laki 13 orang dan lansia perempuan 88 dari total lansia $\mathrm{n}=101$ orang. Lansia perempuan cenderung memiliki kolesterol total meningkat sejumlah 28 orang daripada laki-laki. Kisaran umur 55-64 tahun memiliki kadar kolesterol meningkat ada 16 orang dibandingkan umur lainnya. Lansia gemar konsumsi makanan berlemak memiliki kadar kolesterol total meningkat ada 21 orang, lansia yang tidak gemar konsumsi makanan berlemak ada 8 orang yang meningkat kolesterol totalnya. Hasil pemeriksaan kolesterol total terhadap 101 sampel darah didapat kadar terendah $107 \mathrm{mg} / \mathrm{dl}$ dan tertinggi $301 \mathrm{mg} / \mathrm{dl}$ dengan rata-rata $184 \mathrm{mg} / \mathrm{dl}$. Lansia dengan resiko sedang PJK ada 19 orang dan resiko tinggi PJK ada 10 orang berdasarkan hasil kolesterol totalnya.

Hasil analisis statistik disimpulkan tidak terdapat hubungan signifikan usia dengan kolesterol total $(p=0.067 ; a=0.05)$, tidak terdapat hubungan signifikan konsumsi makanan berlemak dengan kolesterol total $(p=0.057 ; a=0.05)$ dan tidak terdapat hubungan signfikan usia, konsumsi makanan berlemak dengan kolesterol total $(p=0.185 ; a=0.05)$
\end{abstract}

\section{Kata Kunci : Usia-Makanan Berlemak-Kolesterol Total}

\begin{abstract}
Aging brings physical decline and increases morbidity trend, out of many is coronary heart disease(CHD). This disease is the leading cause in Indonesian's total death number and one of the risk factors is hypercholesterolemia. Hypercholesterolemia is influenced by diet, heredity, age, sex, obesity, stress, alcohol, and physical activity. To identify the relationship of age and consumption of fatty food by total cholesterol.
\end{abstract}


It is a descriptive analytical research by applying cross sectional approach. Purposive sampling method is conducted. Data are analyzed using SPSS version 16.0

Result of taking 101 elderly as samples, 13 are male and 88 are female, 28 elderly female tend to have cholesterol increase. The age range of 55 - 64 years old has got the highest cholesterol level than the other age range. Elderly who like to consume fatty food are 21 compared to people who don't like fatty food are only 8. Total cholesterol test result of 101 blood samples obtains $107 \mathrm{mg} / \mathrm{dl}$ for lowest level and $301 \mathrm{mg} / \mathrm{dl}$ for highest level with $184 \mathrm{mg} / \mathrm{dl}$ for average. Elderly with CHD risk are 19 people and high risk of CHD are 10 people based on the total cholesterol result.

The result of the statistical analysis is concluded that there is significant association of age with total cholesterol $(p=0.067, a=0.05)$, there is no significant association with the consumption of fatty foods in total cholesterol $(\mathrm{p}=0.057 ; \mathrm{a}=0.05)$, and there are no significant relationships of age, consumption of fatty foods with total cholesterol $(p=0.185 ; a=0.05)$

\section{Keywords : Age-Consumption of fatty foods-Total cholesterol}

\section{Pendahuluan}

Presentase penduduk lansia Indonesia telah mencapai angka diatas tujuh persen, sehingga Indonesia mulai masuk kelompok negara berstruktur usia tua. Jumlah penduduk lansia yang di atas rata-rata Nasional yakni Provinsi Daerah Istimewa Yogyakarta 14,19 persen, Jawa Timur 11,30 persen, Jawa Tengah 11,12 persen, Bali 10,46 persen, Sulawesi Utara 9,08 persen dan Sumatera Barat 8,97 persen.

Derajat kesehatan penduduk lansia secara umum cenderung rendah. Penduduk lansia dengan keluhan kesehatan sebesar 49,50 persen tahun 2004 dan naik menjadi 55,42 persen di tahun 2008. Tingginya persentase penduduk lansia yang mengalami keluhan kesehatan ditemukan hampir di semua provinsi (Doewes, 2011).

Kota Surakarta sebagai bagian provinsi Jawa Tengah, sebagian besar penduduknya berusia produktif yaitu umur 15-64 tahun (72,07 persen). Sedang 23,62 persen penduduk usia muda (berusia dibawah 15 tahun) dan 4,31 persen penduduk lanjut usia atau 65 tahun ke atas (Dinas Kependudukan dan Pencatatan Sipil Kota Surakarta, 2012).

Masa lanjut usia membawa penurunan fisik lebih besar dibandingkan periode usia sebelumnya. Semakin lanjut usia seseorang, kemungkinan memiliki beberapa penyakit meningkat. Penurunan kekuatan fisik

Volume 2 Issue 1 (2013) membatasi kegiatan orang usia lanjut, penyakit yang melemahkan membuat tidak berdaya (Atkinson, 2003). Penduduk lanjut usia juga mengalami masalah kesehatan selain pendidikan dan kualitas hidup.

Data menunjukkan ada kecenderungan angka kesakitan lanjut usia mengalami peningkatan dari tahun ke tahun. Kondisi ini tentunya harus mendapatkan perhatian berbagai pihak. Lanjut usia yang sakit-sakitan akan menjadi beban keluarga, masyarakat dan pemerintah, sehingga menjadi beban pembangunan.

Salah satu penyebab kematian pasien diatas usia 65 tahun adalah penyakit jantung koroner atau PJK (Dalal dkk, 2002; Safeer $\mathrm{dkk}, 2002)$. Faktor resiko terjadi PJK adalah hiperlipidemia atau hiperkolesterolemia, merokok, hipertensi, diabetes mellitus, alkohol, obesitas (Jong Myon Bae dkk, 2011; Effendy dkk, 2008) sedangkan hiperkolesterolemia dipengaruhi diet, keturunan, umur, jenis kelamin, obesitas, alkohol, dan exercise (Djohan, 2004).

Peneliti Saint Lois University School of Medicine menyimpulkan kolesterol berperan dalam proses aterosklerosis sehingga meningkatkan risiko serangan jantung dan stroke. Hal tersebut dikarenakan mensupresi aktivitas suatu protein yang memproteksi jantung dan pembuluh darah. Hasil studi 
Jung San Huang (2007) menyatakan secara bermakna kolesterol membatasi aktivitas protein protektif TGF-beta (transforming growth factor beta) sehingga mengalami upregulated pada plak ateroklerosis manusia. Penelitian ini bertujuan mengetahui hubungan usia dan konsumsi makanan berlemak dengan kolesterol total.

\section{Metode Penelitian}

\section{Desain Penelitian}

Penelitian ini menggunakan rancangan analitik deskriptif dengan pendekatan cross sectional.

\section{Subjek Penelitian}

Pengambilan sampel penelitian digunakan purposive sampling sedangkan besar sampel penelitian dengan totalitas sampling. Subjek penelitian yakni lansia di kelurahan Serengan yang memenuhi kriteria inklusi penelitian: umur $\geq 55$ tahun, tidak konsumsi obat anti kolesterol, tidak konsumsi obat antihipertensi, dan tidak merokok.

\section{Pengumpulan Data}

Lansia terpilih ada 101 dari 121 orang, diberikan penjelasan tujuan penelitian dan pemeriksaan laboratorium yang akan dilakukan serta kesediaan dengan mengisi inform consent. Wawancara dilakukan bulan Juli
2011 dengan kuesioner terstruktur. Pengumpulan sampel darah vena dilakukan untuk mengukur kadar kolesterol total. Pengukuran kadar kolesterol total menggunakan metode CHOD-PAP. Pemeriksaan kadar kolesterol dilakukan di laboratorium klinik Akademi Analis Kesehatan Nasional Surakarta. Harga Rujukan Dewasa :

Nilai ideal $\quad:<200 \mathrm{mg} / \mathrm{dL}$

Resiko Sedang $\quad: 200-240 \mathrm{mg} / \mathrm{dL}$ Resiko Tinggi : $>240 \mathrm{mg} / \mathrm{dL}$

Kehamilan : kadar beresiko tinggi, tetapi akan kembali ke kadar seperti sebelum kehamilan, yaitu 1 bulan setelah kelahiran (Kee, 2007)

\section{Pengolahan Data}

Data penelitian diolah menggunakan program SPSS versi 16.0 dengan tingkat kemaknaan uji statistik besarnya 0.05

\section{Hasil dan Pembahasan}

\section{A. Hasil}

Data hasil penelitian berdasarkan jenis kelamin terlihat lansia pria sejumlah 13 orang $(12.9 \%)$ dan lansia wanita $88(87.1 \%)$ dari total lansia $n=101$ orang terlihat pada gambar 1.

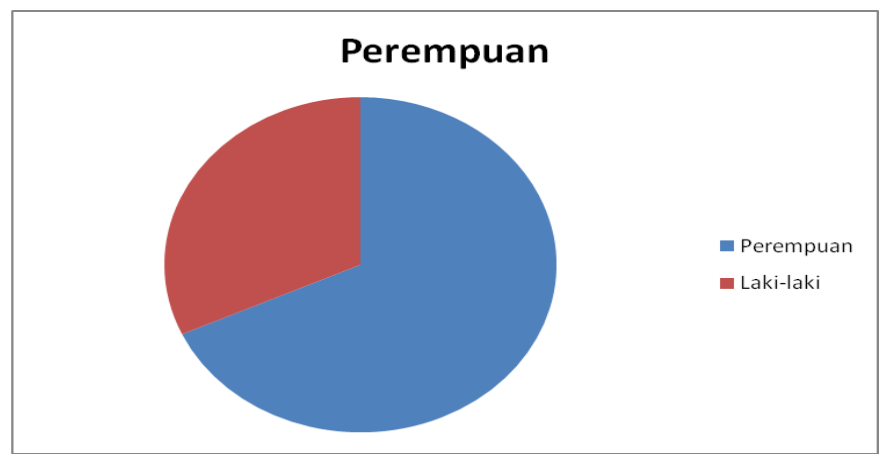

Gambar 1. Distribusi Lansia Berdasar Jenis Kelamin

Hasil kuesioner yang dibagikan tentang kegemaran makanan berlemak (konsumsi makanan berlemak) didapatkan lansia yang suka mengkonsumsi makanan berlemak sejumlah 73 orang $(72.3 \%)$ dan lansia yang tidak suka konsumsi makanan berlemak sejumlah 8 orang $(27.7 \%)$, hal tersebut tampak pada gambar 2 . 


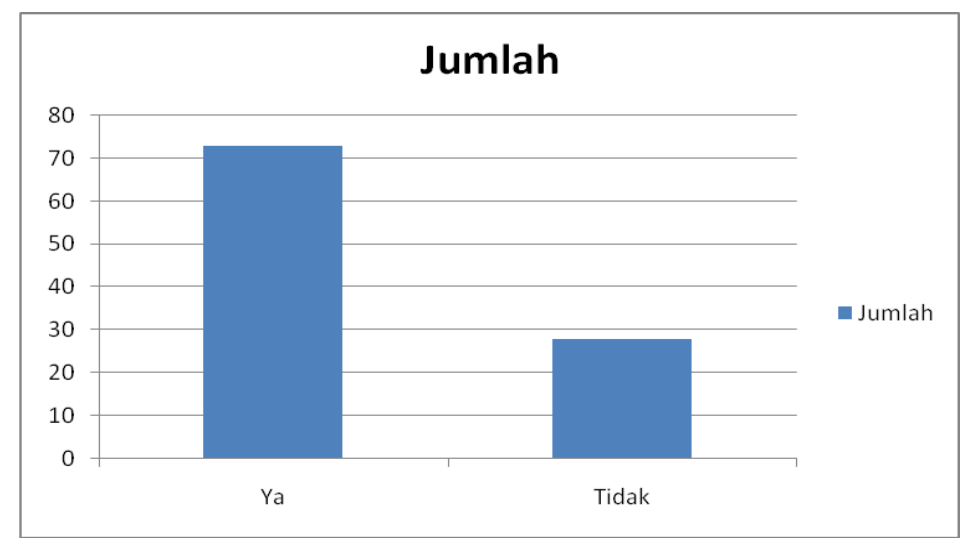

Gambar 2. Frekuensi Kegemaran Konsumsi Makanan Berlemak.

Tabel 1 memperlihatkan perempuan cenderung memiliki kolesterol total meningkat sejumlah 28 orang daripada laki- laki. Hal ini dapat karena perempuan mengalami menopause berakibat kadar kolesterol meningkat lebih tinggi daripada laki-laki (Djohan, 2004).

Tabel 1. Distribusi Silang Jenis Kelamin Dengan Kolesterol Total

\begin{tabular}{lcc}
\hline Jenis Kelamin & Kolesterol Total Normal & Kolesterol Total Meningkat \\
\hline Perempuan & 60 & 28 \\
Laki-laki & 11 & 2 \\
\hline
\end{tabular}

Tabel 2. Tabulasi Umur dengan Kolesterol Total

\begin{tabular}{ccc}
\hline Umur & Kolesterol Total Normal & Kolesterol Total Meningkat \\
\hline $55-64$ & 37 & 16 \\
$65-74$ & 19 & 11 \\
$>74$ & 16 & 2 \\
\hline
\end{tabular}

Tabel 2 memperlihatkan kisaran umur 55-64 tahun memiliki kadar kolesterol meningkat ada16 orang dibandingkan kisaran umur lainnya. Hasil ini selaras dengan penelitian Bintanah dan Muryati (2008) di RSU Kraton Kabupaten Pekalongan didapatkan hiperkolesterolemia terjadi kisaran umur 55-64 tahun.

Tabel 3. Tabulasi Konsumsi Makanan Berlemak Dengan Kolesterol Total

\begin{tabular}{ccc}
\hline Konsumsi Makanan Berlemak & Kolesterol Total Normal & Kolesterol Total Meningkat \\
\hline Ya & 52 & 21 \\
Tidak & 20 & 8 \\
\hline
\end{tabular}

Tabel 3 memperlihatkan secara deskriptif, sampel yang gemar konsumsi makanan berlemak memiliki kadar kolesterol total meningkat ada 21 orang, lansia yang tidak gemar konsumsi makanan berlemak ada 8 orang. Hasil diatas sesuai penelitian Bintanah dan Muryati (2008).
Tampak pada tabel 4, lansia yang beresiko sedang PJK ada 19 orang dan beresiko tinggi PJK ada 10 orang.

Mean usia adalah 65.63 sedang kolesterol total $184.26 \mathrm{mg} / \mathrm{dl}$. Nilai SD usia yakni 7.647 dan kolestrol total 39.399. Nilai minimum usia yaitu 55 tahun dan kolestrol total 107 $\mathrm{mg} / \mathrm{dl}$. Nilai maximum usia 81 tahun dan kolestrol total $301 \mathrm{mg} / \mathrm{dl}$ 
Tabel 4. Deskriptif Kadar Kolesterol Total Dan Resiko PJK

\begin{tabular}{ccc}
\hline Klasifikasi Kolesterol Total & Jumlah & Resiko PJK \\
\hline$<200 \mathrm{mg} / \mathrm{dL}$ & 72 & Ideal \\
$200-240 \mathrm{mg} / \mathrm{dL}$ & 19 & Sedang \\
$>240 \mathrm{mg} / \mathrm{dL}$ & 10 & Tinggi \\
\hline
\end{tabular}

Tabel 5. Deskriptif Usia Dan Kolestrol Total

\begin{tabular}{lcccc}
\hline Hal & Mean & SD & Minimum & Maximum \\
\hline Usia & 65.63 & 7.647 & 55 & 81 \\
Kolesterol Total & 184.26 & 39.399 & 107 & 301 \\
\hline
\end{tabular}

\section{B. Pembahasan}

Salah satu faktor resiko PJK yakni hiperkolesterolemia disamping hipertensi dan merokok. Kadar kolesterol darah dipengaruhi susunan makanan sehari-hari yang masuk tubuh (diet). Tabel 3 memperlihatkan sampel yang gemar konsumsi makanan berlemak ternyata memiliki kadar kolesterol total meningkat sebesar 20.8\% Kadar kolesterol orang Jepang rata-rata rendah karena konsumsi nasi dan sayur-sayuran serta ikan sehingga resiko PJK lebih rendah dari Amerika. Orang Amerika rata-rata konsumsi makanan mengandung lemak dan kolesterol tinggi sehingga kadar kolesterol cenderung meningkat dan resiko PJK lebih tinggi

Orang Eskimo dan Jepang banyak mengkonsumsi ikan dalam jumlah besar ternyata insidens PJK sangat rendah. Lemak ini banyak terdapat pada ikan laut yang berasal dari daerah dingin seperti ikan saimon, ikan baring dan ikan air tawar. Asam lemak omega-3 sifatnya:

1. mencegah pengumpulan platelet atau pembekuan pada pembuluh darah

2. menurunkan kadar trigliserid dan LDL kolesterol (Anwar, 2004).

Pada dekade terakhir ini jumlah lemak pada diet orang Amerika jauh menurun dan ternyata kejadian PJK ikut menurun. Jadi diet merupakan faktor penting yang berpengaruh terhadap tinggi rendahnya kolesterol darah (Djohan, 2004).

Tabel 2 memperlihatkan kisaran umur 55-64 tahun memiliki kadar kolesterol meningkat ada16 orang dibandingkan kisaran umur lainnya. Tabel 1 tampak perempuan cenderung memiliki kadar kolesterol total meningkat dari laki-laki. Hasil penelitian membuktikan ada hubungan usia dengan kematian akibat PJK. Peningkatan kadar kolesterol laki-laki dan perempuan dimulai umur 20 tahun. Kadar kolesterol laki-laki meningkat sampai umur 50 tahun sedang kadar kolesterol perempuan sebelum menopause lebih rendah dari laki-laki pada tingkat umum sama (Djohan, 2004). Hasil ini selaras penelitian Bintanah dan Muryati (2008) di RSU Kraton Kabupaten Pekalongan didapat hiperkolesterolemia terjadi kisaran umur 55-64 tahun. Saat belum menopause, estrogen berfungsi meningkatkan anabolisme protein serta pembentukan HDL dan LDL. Hormon ini juga mengurangi konsentrasi LDL sehingga resiko aterosklerosis rendah. Sedangkan perempuan menopause terjadi defisiensi estrogen berakibat kadar kolesterol meningkat sehingga resiko aterosklerosis bertambah (Silbernagl,2003).

Adapun hasil perhitungan statistik disimpulkan tidak terdapat hubungan signifikan usia dan konsumsi makanan berlemak dengan kolesterol total. Hasil penelitian ini bertolak belakang dengan penelitian Megawati H (2010) bahwa terdapat hubungan yang signifikan antara proporsi lemak yang tinggi berhubungan dengan peningkatan kadar kolesterol total.

Hasil penelitian ini juga berlawanan dengan hasil penelitian Bintanah dan Muryati (2008) terhadap 17 pasien poliklinik jantung di RSU Kraton Kabupaten Pekalongan didapatkan ada hubungan signifikan konsumsi lemak dengan kejadian hiperkolesterolemia dengan $\mathrm{p}=0.016$ dan alfa $=0.05$.

Data deskriptif memperlihatkan sekalipun lansia gemar mengkonsumsi makanan berlemak ternyata memiliki kadar kolesterol total dalam batas normal (tabel 3), hal ini dapat terjadi : 
1. Tingkat kesadaran kesehatan para lansia tinggi dengan rutin datang ke posyandu memeriksakan kesehatan terutama cek tekanan darah dan timbang berat badan sehingga sebagian besar lansia tidak mengalami obesitas bahkan beberapa memiliki berat badan dibawah normal akibat penurunan nafsu makan seiring berjalannya usia mereka.

2. Sekalipun suka mengkonsumsi makanan berlemak, para lansia juga mengimbangi dengan aktivitas fisik sehingga lemak yang tertimbun segera dibongkar menjadi energi yang digunakan aktivitas fisik kembali.

3. Perbedaan asal subjek penelitian yang berpengaruh pada pola makannya dan cara memasak bahan sumber kolesterol (gulai, santan, otak) dengan mengkombinasikan bahan protein nabati sehingga diduga efek hiperkolesterol lebih rendah (Sulastri; Rahayuningsih; Purwatyastuti, 2005).

4. Kemungkinan tidak adanya keturunan, stress, dan kebiasaan minum alkohol, yang ditemukan pada lansia tersebut (Djohan, 2004 ).

Data deskriptif juga terlihat sebagian kecil lansia memiliki kadar kolesterol total diatas harga rujukan normal (tabel 4), hal tersebut dapat dimungkinkan :

1. Diet tinggi kolesterol yang dikonsumsi sebelum pemeriksaan dapat menyebabkan peningkatan kadar kolesterol serum.

2. Puasa yang belum mencapai 12 jam sehingga pengaruh dari makanan yang dikonsumsi masih ada apalagi mengkonsumsi makanan tinggi lemak.

3. Hipoksia berat dapat meningkatkan kolesterol serum.

4. Hemolisis pada specimen darah dapat menyebabkan peningkatan kadar kolesterol serum (Kee, 2007).

Penelitian ini masih memiliki keterbatasan, sehingga disarankan:

1. Penelitian lanjut mengenai faktor yang berpengaruh terhadap kolesterol total plasma juga profil lipid lainnya (trigliserida, HDL, dan LDL )

2. Penambahan sampel penelitian sehingga lebih mewakili populasi penelitian.

3. Instrumen penelitian konsumsi makanan lemak lebih detail lagi sehingga mendapatkan data yang lebih terperinci.

\section{Kesimpulan}

Hasil penelitian disimpulkan tidak terdapat hubungan yang signifikan usia dan konsumsi makanan berlemak dengan kolesterol total pada lansia.

\section{Ucapan Terima Kasih}

Terima Kasih kepada Pimpinan Akademi Analis Kesehatan Nasional dan Kepala Kalurahan Serengan Surakarta yang telah mendukung penelitian ini. Semoga kerjasama ini terus berlanjut dan berjalan lebih baik lagi. Peneliti juga mengucapkan terima kasih kepada para lansia yang mengikuti penelitian ini.

\section{Daftar Pustaka}

Alfikri A. 2008. Keperawatan Gerontik. http://ahmadalfikri.blogspot.com/2 008/05/batas-batas-lanjut-usia.html diunduh pada April 2011

Almatsier S. 2002. Prinsip Dasar Ilmu Gizi. Cetakan kedua. Jakarta. Gramedia. Hal:51-76

Anwar TB. 2004. Faktor Resiko Penyakit Jantung Koroner. Universitas Sumatra Utara. http://library.usu.ac.id/download/f k/gizi-bahri4.pdf diakses Februari $\underline{2012}$

Atkinson, Rita L, Richard C., Hilgard Ernest R. 2003. Pengantar Psikologi. Edisi Kedelapan. Jilid I. Jakarta. Erlangga

Bintanah S, Muryati. 2008. Hubungan Konsumsi Lemak Dengan Kejadian Hiperkolesterolemia Pada Pasien Rawat Jalan Di Polilinik Jantung Rumah Sakit Umum Daerab Kraton Kabupaten Pekalongan http://jurnal.unimus.ac.id diakses Maret 2011

Dalal D, Robbins JA. Management of byperlipidemia in the elderly population: an evidence-based approach. South Med J 2002; 95: 1255-61.

Dinas Kependudukan dan Pencatatan Sipil Kota Surakarta. 2012. Penduduk Menurut Karakteristik Demografi .http:// dispendukcapil.surakarta.go.i d/index.php/profilpenduduk/tahun- 
2012/90-kuantitaspenduduk/97pendudukmenurutkarakteristikdemo grafi. Diakses Februari 2012

Djohan T.B.A. 2004. Penyakit Jantung Koroner dan Hipertensi. library.usu.ac.id/download/fk/giri-

babri10.pdf diakses pada 4 Agustus 2011

Doewes M. 2011. Indonesia Masuk Kelompok Negara Berstruktur Tua. http://www.republika.co.id/berita/ breakingnews/internasional/11/03/08/1679 73-indonesia-masuk-kelompoknegara-berstruktur-tua diakses Februari 2012

Effendy N dkk. 2008. Prediksi Penyakit Jantung Koroner Berdasarkan Faktor Resiko Menggunakan Jaringan Syaraf Tiruan Backpropagation. http://journal.uii.ac.id/index.php/S nati/article/viewFile/725/680 akses 10 Juni 2011

Isselbacher; Braunwald; Wilson dkk. 2000. Prinsip-prinsip Ilmu Penyakit Dalam. Edisi 13. Volume 5. Jakarta. EGC

Jong Myon Bae et al. 2011. Low Cholesterol is Associated with Mortality from Cardiovascular Diseases: A Dynamic Cohort Study in Korean Adults. http://www.ncbi.nlm.nih.gov/pmc/ articles/PMC3247776/pdf/ikms-2758.pdf diakses Maret 2011

Makmun LH . 2007. Penyakit Jantung pada Usia Lanjut, dalam Ilmu Penyakit Dalam FK UI. Jakarta. EGC. Hal:1649

Megawati H. 2010. Hubungan Pola Makan Dengan Kadar Kolestrol Darah Total Pada Penderita Penyakit Jantung Koroner Laki-laki Di
Rumah Sakit Umum Raden Ajeng Kartini Jepara. eprints.undip.ac.id/17191/1/3820.pdf diakses 2 Agustus 2011

National Cholesterol Education Program Adult Panel III. 2001. Klasifikasi Kolesterol dalam Dislipidemia. Ilmu Penyakit Dalam Jilid III. Jakarta. EGC. Hal:1928

Rustika. 2001. Pengembangan Model Penyuluban Faktor-faktor Risiko Penyakit Jantung Koroner (PJK) Pra Lansia melahi Peran Keluarga (Lanjutan)Research $\underline{\text { Report }}$ from JKPKBPPK. Rustika@litbang.depkes.go.id_akses pada tanggal 10 Juni 2011

Safeer RS, Ugalat PS. Cholesterol treatment guidlines update. Am Fam Physician 2002; 65 871-80.

Silbernagl S;Florian Lang. 2003. Atlas Berwarna Patofisiologi. Jakarta. EGC. Hal:276

Suhardjono. 2007. Hipertensi pada Usia Lanjut dalam Ilmu Penyakit Dalam FK UI. Jakarta. EGC

Sulastri D;Rahayuningsih S;Purwatyastuti. 2005. Pola Asupan Lemak, Serat, dan Antioksidan, serta Hubungannya dengan Profil Lipid pada LAki-laki Etnik Minangkabau. Majalah Kedokteran Indonesia. Volume 55. Nomor 2

, 2008. Penjelasan Baru Hubungan Kolesterol dan Penyakit Jantung dalam Journal of Cell Science 2007, doi:10.14/jcs.006916 www.pjnhk.go.id/index2.php?option Ecom content\&do pdf=1\&id... Akses pada 4 Agustus 2011 